Journal of Law \& Social Studies (JLSS)

Volume 2, Issue 2, pp 58-65, 2020

www.advancelrf.org

\title{
Legislations in Parliament of Canada and Pakistan: A Comparative Study of House of Commons and National Assembly
}

\author{
Sidra Akram \\ $\mathrm{PhD}$ Scholar, Department of Political Science and International Relations, \\ Government College University Faisalabad, \\ Email: sidraakram200015@gmail.com \\ Dr. Mian Muhammad Azhar \\ Assistant Professor, Department of Political Science \& IR \\ G. C. University, Faisalabad \\ Email: Muhammad.azhar@gcuf.edu.pk
}

\begin{abstract}
Parliament is an exclusive and unique representative institution and performs key functions such as law-making, representation of constituents, amending laws, highlighting and aspirations their issues and through resolutions prescribe solutions to such key challenges faced by the polity. Parliament established on the behalf of people to represent their voice and provide them opportunities for more participatory and open governance. This research focused upon the performance of both lower Houses of Canada and Pakistan in $21^{\text {st }}$ Century. The performance of the parliamentarian will also examine in this study. This comparative study will extend the boundaries of comparative politics and system analysis theory.This research discussed the role of parliament and basically the legislation process in parliament. Legislation in parliaments of new democracies and comparative study is useful research topic in Political Science and will provide a guideline to parliamentarians to work better.
\end{abstract}

Key Words: Parliament, House of Commons, National Assembly, Legislation

\section{Introduction}

Parliaments are an indispensable component of the democratic architecture, but their prominence varies considerably. However, Parliament is the symbol of the will of people, custodian of citizen rights, and writer of the pluralistic constitution. Parliament gets direct power from the opinions of the citizens, who expressed their opinions by the votes/elections, and it survives to execute the will of people. It makes sure the possible participatory democratic system and active dealings among the people and their elected representatives (Ahmed,2014).

Parliament is responsible for legislation, changing and making the laws to bring desired and beloved social changes in the behavior of the state citizens. Generally, the executive keeps effective control of legislation, Parliamentarians are considered as public representative's policy makers. They make policies and laws for the welfare of the nation. These decision makers performed their duties as per their extreme skill to secure national interests. It plays a vital and major role through the legislation and socio-economic transformation of society (PIPS, 2014).

However, the Parliamentary systems of Pakistan and Canada are adopted from the Westminster system. Westminster system is based supremacy of the parliament at the wishes of the citizens. Prime minister belongs to parliament and head of government. The Head of the state is considered as a symbol of unity and plays the role as a formal supreme authority in legislation. Westminster system is considered the parliamentary democratic system which is running with the full spirit in Canada, Pakistan, Britain, New Zealand, Australia, India, and others countries. The origin of the parliamentary system can be traced out from the concept of Westminster political system. The term of Westminster system comes from the 'Palace of Westminster' where was held the model parliament of 1295. The Westminster System of parliamentary government was developed over centuries (Whitehead, 2013).

Westminster system is based on the precedents, practices, and conventions of the UK Parliament. Most of the countries unlike the UK have codified the Westminster system in a written constitution. However, in these states' precedents, 
practices and conventions continued to perform a momentous role. As many constitutions don't stipulate significant elements of procedure. The Westminster system is using within the older constitutions, such as the Australian and Canadian constitutions (Pollard, 1926).

\section{Research Questions}

i. What is the performance of both lower Houses of Canada and Pakistan in $21^{\text {st }}$ Century?

ii. The role of parliament and basically the legislation process in parliament

\section{Research Methodology}

Data related to this study collected by secondary sources such as governmental official records, reports, articles, books and journals. This research work is analytical as well as descriptive in nature. Qualitative technique has applied to investigate the research questions. This comparative study will extend the boundaries of comparative politics and system analysis theory.

\section{Canadian Parliament}

Canada is a federal state as well as an independent sovereign democracy. The Canadian parliament is the body of federal legislature. It is seated in Ottawa (national capital city) at Parliament Hill. It has the constitutional monarchy which means all federal laws are made in the Queen's name. The Canadian parliament consisted on British Queen (Crown) is head of state in Canadian political system that performed every act of government, the House of Commons which is a dominant institution and called it MPs (members of Parliament), and the Senate which is an upper House. Each element has its own organization and officers. The Canadian House of Commons consisted upon 338 members which are democratically elected directly through Canadian voters and represented an electoral district. In the Canadian House of Commons, the Constitution Act provides for the distribution and size of representation as well as redistributions or readjustments in future. The Canadian House of Commons seats distribution are as following:

\begin{tabular}{|l|l|l|l|}
\hline Canadian Seats Allocation in House of Commons \\
\hline Sr \# & Canadian Provinces & $\begin{array}{l}\text { Number of SeatsAccordancewith } \\
\text { Constitution Act }\end{array}$ & $\begin{array}{l}\text { Allocated Seats Accordance with } \\
\text { Previous Elections }\end{array}$ \\
\hline 1 & Ontario & 75 & 121 \\
\hline 2 & British Columbia & 34 & 42 \\
\hline 3 & Alberta & 26 & 34 \\
\hline 4 & Quebec & 75 & 78 \\
\hline 5 & Saskatchewan & 14 & 14 \\
\hline 6 & Prince Edward Island & 04 & 04 \\
\hline 7 & Manitoba & 14 & 14 \\
\hline 8 & New Brunswick & 10 & 10 \\
\hline 9 & Newfoundland & 07 & 07 \\
\hline 10 & Nova Scotia & 11 & 11 \\
\hline 11 & Yukon Territory & 01 & 01 \\
\hline 12 & Nunavut & 01 & 01 \\
\hline 13 & North west Territories & 01 & 01 \\
\hline & Total & 282 & 338 \\
\hline
\end{tabular}

(Compiled by Author)

\section{Pakistan's Parliament}

Pakistan's parliamentary system is bicameral and consisted of two Houses, National Assembly and Senate. Pakistan is based upon Parliamentary democracy; it is the representative democracy in which people of any state casting the vote to the professional politicians and elected them as the member of the Parliament rather than direct ruling. The president, indirectly "elected by an electoral college, is the head of state and the Prime Minister as the head of the government" (Lauise.A, 2013).National assembly of Pakistan is consisted of 342 members who are democratically elected body and referred to as MNAs. In these 342 members, 272 are elected directly, 70 are on reserved seats for religious minorities and women.Members of the assembly symbolize the various political parties that participated in the elections. The Pakistan's National Assembly seats allocations are given here in detailed: 


\begin{tabular}{|l|l|l|l|l|}
\hline \multicolumn{2}{|l|}{ Seats Allocation in the Pakistan's National Assembly } \\
\hline Sr \# & Provinces of Pakistan & $\begin{array}{l}\text { Provinces wise General } \\
\text { seats in NA }\end{array}$ & $\begin{array}{l}\text { Total reserved seats for } \\
\text { Women }\end{array}$ & Total \\
\hline 1 & Baluchistan & 14 & 03 & 17 \\
\hline 2 & Punjab & 148 & 35 & 183 \\
\hline 3 & KPK & 35 & 08 & 43 \\
\hline 4 & Sindh & 61 & 14 & 75 \\
\hline 5 & FATA & 12 & 00 & 12 \\
\hline 6 & Federal Capital & 02 & 00 & 02 \\
\hline 7 & Non-Muslim & 10 & 00 & 10 \\
\hline 8 & Grand Total & 282 & 60 & 342 \\
\hline
\end{tabular}

(Compiled by Author)

\section{LegislationProcess in Canadian House of Commons}

One of the most momentous tasks of any Parliament is legislation. Law-making refers to written laws which are often referred to as statutes or Acts. Then these are enforced through parliament and governmental legislative arm. Therefore, it's not surprising that the process of legislation takes Parliament's major portion of time (Hasson, 2017). The parliamentary stages are the culmination of a process of much longer which begins with the bill formulation, drafting and proposal. All legislative assemblies in the Canadian parliament are based upon the British model. Draft legislation is called a bill. However, legislation process from draft to bill and bill to become an Act there is need of approval from both lower and upper houses and then finally requires assent of Crown to declare it a law. (Rizvi D. H., 2013). For enacted legislation, there is a clearly defined procedure, and a bill has to go through by various definite stages for becomes the law or an Act(Marc Basc, 2017).

\subsection{Different Stages of Legislation in Canadian House of Commons}

Parliaments are the central institutions of government and it is also an institution of the elected representatives that makes law for the state. Sometime, the word parliament, used to describe the legislature process. The legislation is the major and predominant function of parliament. Both Houses of Parliament, work together with full cooperation to carry out the basic work of legislation. However, the primary function of parliament is law making. Parliament or its members safeguard the interest of the people and protect their rights, and each member of the parliament represents the people of the certain area. In the Parliamentary system legislature and executive combined work with full cooperation (Bourinot, 2008).Before becoming an Act, a bill passesthrough different stages, which are following:

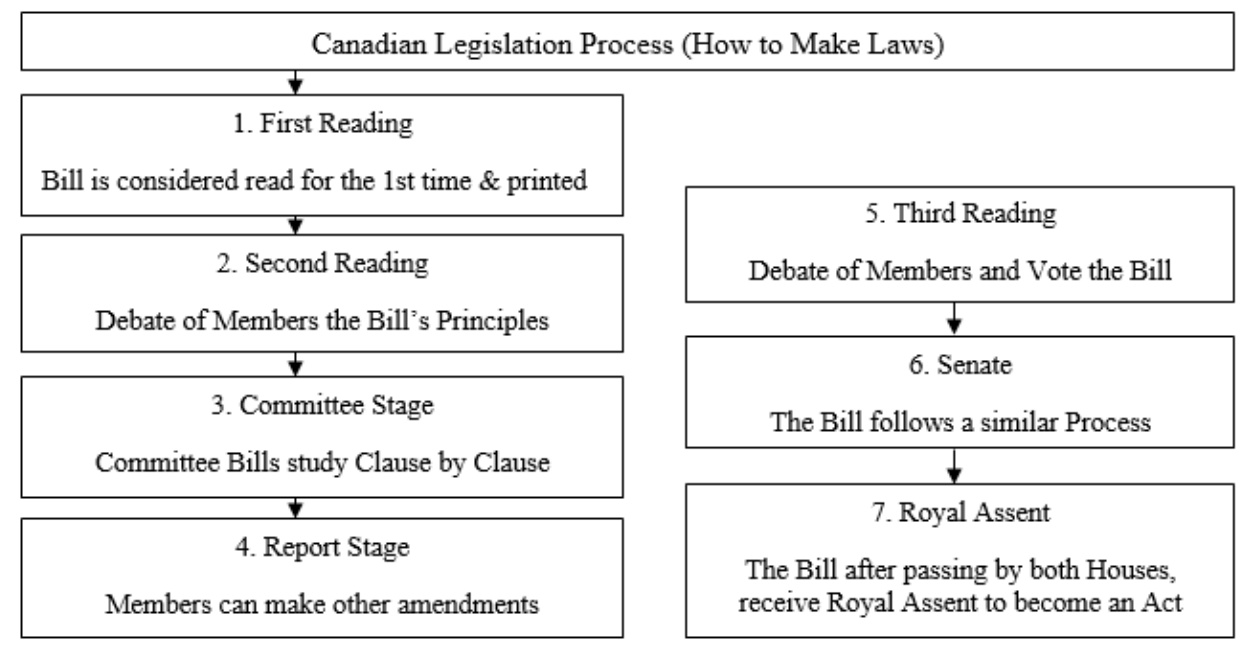

\subsubsection{First Reading and Introduction of a Bill}

Any public bill requires written notice within 48 hours for the introduction of bill. However, a minister or a member of house of common must firstly give notice before $6 \mathrm{pm}$ to the clerk of the House, to introduce a bill. The bill title is to be introduced and then for the House next sitting it is placed on the Notice Paper. After it's appearing on the Notice Paper, in the Order Paper the bill title appear for introduction in the House (Malcolmson, 2012). The bill title remains 
on the Order Paper till the day on which the Minister or member of the house decided to introduce the bill. Once the introduction notice of a bill is given, then there is no further requirement of notice for the bill consideration at other stages.

\subsubsection{Members Debate the Bill's Principles}

In the legislation process the stage of second reading gives an opportunity to Members for debate the general scope of that bill. In this debate must focus upon the text and principles of that bill and then is referred to the related committee. However, a bill cannot refer to a related committee prior to debate of second reading. But a minister can move a government bill without second reading to the committee. Doing so, it allows committee members to examine the bill's principles "before it is approved by the House of Commons and to propose amendments to alter its scope"(Jackson, D. J, 2008). However, this process can too apply bills based on means and ways of motions (Beauchesne, 12 March 2012).

\subsubsection{Committee Stage}

The house of common may decides to move a bill to a committee of legislature. So, the bills are sent to those standing committee whose mandate is much corresponds subject matter and closely related to that bill.Here's the role of standing committee is to review the bill's text its approval and then to modify.Witnesses are invited at this stage to present their views and member's answers questions before the committee. Then, clause-by-clause the bill is studied by the proceedings of committee after hearing the witnesses. The committee members can suggest the amendments to the bill at this point.It's separately considered each of the clause. The committee votes, after considering all the parts of the bill. "Once the bill is adopted, the Chair asks the committee for leave to report the bill to the House" (Peter Oliver, 2017).

\subsubsection{Report Stage}

After committee consideration, in the house there is a chance to study the bill further. This stage is called report stage.At this stage, members who are not committee members particularly can suggest motions to amend the bill's text.At the report stage cannot debate unless proposed the amendments. If the committee reported the bill with no amendment at report stagethen immediately it can forward for adoption to the third reading(Bourinot, 2008).

\subsubsection{Third Reading}

At this stage it is decided by the member of House of Commons, whether the bill would be adopted or not. However, third reading is the final stage for the adoption of bill in the House of Commons. "Debate at this stage of the legislative process focuses on the final form of the bill.Once motion for third reading has been adopted"(Jackson, 2016), then the House of Commons clerk gives approval for the adoption of bill and with a requesting message bill sent to the senate for consideration (Bosc, 14 Dec, 2017).

\subsubsection{Consideration of Senate}

The legislative process in the Senate is also very similar to the House of Commons.The senate gives consideration and opinions and often makes amendments upon the bill some of them are involve about the errors of drafting corrections or aspects of administrative improvements. Normally such types of amendments are accepted by the House.In case if the amendments of senate are not accepted "it adopts a motion stating the reasons for its disagreement, which it communicates in a message to the Senate.If the Senate wishes the amendments to stand nonetheless, it sends a message back to the House"(Barnes, 2012), then proposed changes can be rejected or accepted. In such cases, if the senate is adopting any bill without any amendment, then it is informed to the House of Commons and granted normally for royal assent.

\subsubsection{Crown or Royal Assent}

At this stage a bill receives final assent through crown to become an Act of parliament. However, unless a bill after gone through the legislative process of all stages, it cannot receive a royal assentin one of the two ways which are granted for royal assent to any bill, first one is traditional ceremony and the other one is written procedure, "during which Members of the House of Commons join their Senate colleagues in the Senate Chamber" (Peter Milliken, 2009). After getting royal assent a bill comes into force after becoming law(Franks, 1987).

\section{Legislation Process in Pakistan's National Assembly}


National assembly considered the most active component of the parliament and keeps check on the government through the standing committee, question hour, adjournments motion and the debates, because these debates approves decisions regarding policies drafted by the government only for the national interest of the state(Hussain, 2011).

The procedures to introduce or adoption of bills is mentioned in article 70-77 and it is mutually dependent on both Houses of Pakistan's parliament. National Assembly enjoys an exclusive jurisdiction in the assembly except for the money bills(Rizvi D. H., 2013). The Bills are proposed form and discussed in detail. If bill is passed by both houses and signed by president, it becomes an Act. In the private member bills after giving ten days' written notice a member may leave for move. Before becoming an Act, a bill must pass different stages in the parliament of Pakistan which are following:

\subsection{Different Stages of Legislation in Pakistan's National Assembly}

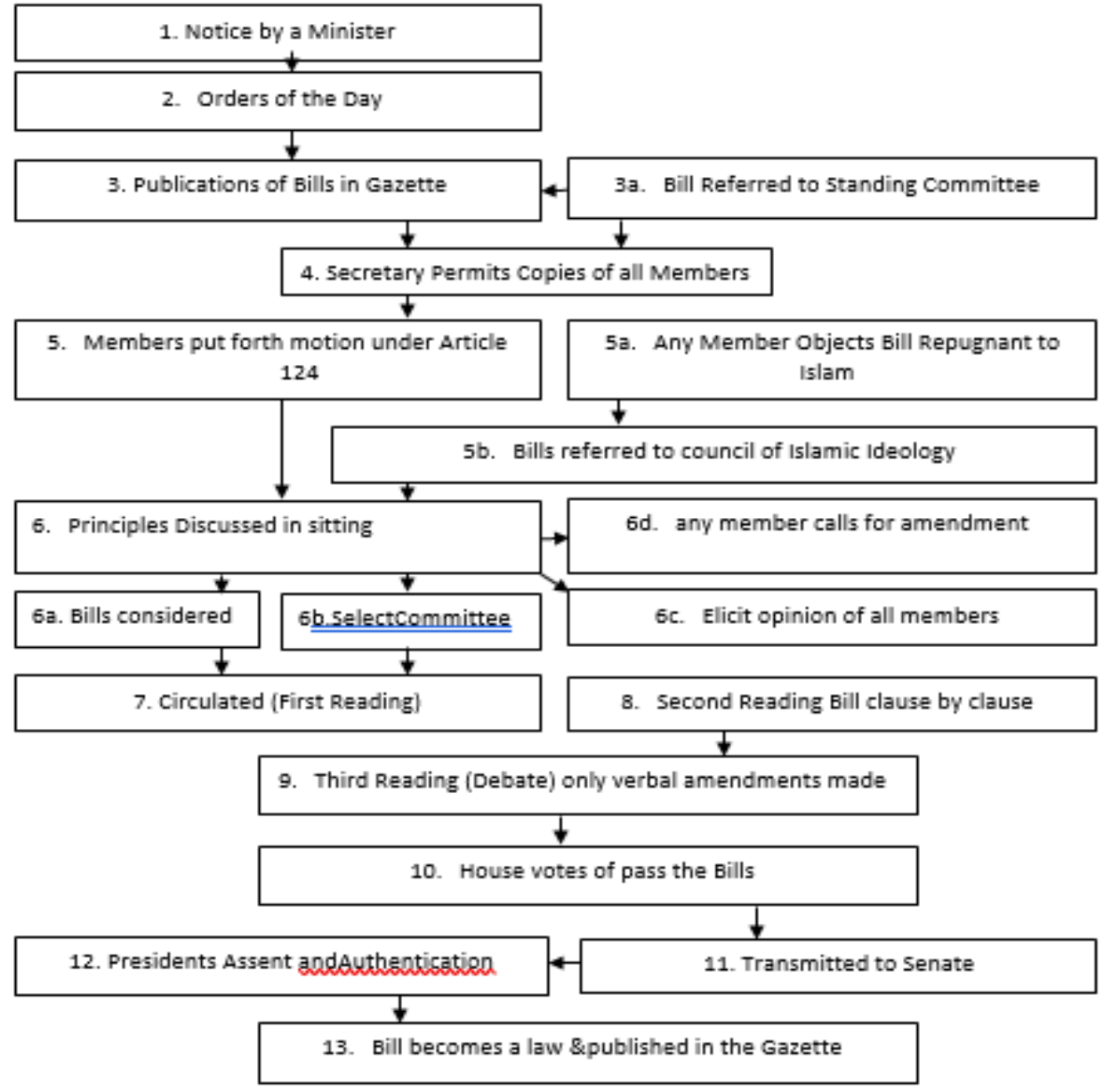

\subsubsection{Introducing a Bill}

Firstly, the provisions and the principles of the bill discussed when a bill comes up for the consideration. If necessary then a point can be discussed and explain its principles, otherwise detail of the bill cannot be discussed. However, to move a bill in the assembly, three copies along with reasons and objectives statements of that bill accompany written notice of 10 days are send to the secretary of the Assembly (Pakistan Institute of Legislative Development and Transparency, 2013).

\subsubsection{Oder of the Day}

It is set down on order of the day for private member's day to introduce a bill of private member's, and then the copies of the private member bills are circulated among the whole assembly members. In next, a bill is referred to the Council 
of Islamic Ideology (it is the body of constitutional advisory on the issues of Islamic law) to judge or examine a bill according to Islamic teachings for advice (Bildook, 2012).

\subsubsection{First Reading \& Bill Discussion upon its Principles}

Then, a bill is circulated between the Assembly members for discussing its principles and getting their opinions. The bill details will not be further discussed in detail than it is necessary according to rule toexplain principles of it. However, to the bill amendments can't move at this stage (Ahmad, 2017).

\subsubsection{Motion of Consideration}

At this stage, all member opinions upon bill can be drown out or elicited or a bill referred to the selected relevant committee after the consideration. However, at this stage the conditions to handle a bill with the rules and procedures are following here: Firstly, the provisions and the principles of the bill discussed when a bill comes up for the consideration. If necessary then a point can be discussed and explain its principles, otherwise detail of the bill cannot be discussed. Secondly, any member can move a bill in next stage (which is circulated for the purpose of opinion) after consideration with a suitable amendment and within a specified time of that motion. Thereafter, the bill is referred to the select committee or to the concerned standing committee for further consideration (Bildook, 2012).

\subsubsection{Referred to Standing Committee}

Over the years, parliamentary committees became an indispensable and integral part of the legislative system.It regards the brain, eyes, hands, and ears of the government in the parliamentary democracies. "The ever-increasing complexity of a legislature's role has resulted in a corresponding increase in reliance on committees. The committees are now recognized (Ahmad, 2017) to be the gatherers of information and the refiners of legislative detail. The committees can allow the consideration of bill with taken into as a whole or with amendments, or additional provisions, or to make it particular with some instructions, or with particular clauses in the bill and then presents the final report to the Assembly (Ahmad, 2017).

\subsubsection{Second Reading}

After bill circulation and final committee report, the bill undergoes for second reading. At this stage, the whole bill reads out entirely clause by clause "and the Speaker decides if amendments proposed meet conditions of admissibility. The National Assembly Rules of Procedure provide that the Speaker may call each clause separately, and when the amendments relating to it have been dealt with, he shall put the question. That this clause (or that this clause as amended) do stand part of the Bill (Bildook, 2012).

\subsubsection{Third Reading}

"When a motion that a bill be taken into consideration has been carried and no amendment is made, the minister who introduced the bill may immediately move for the bill's passage (Bildook, 2012). At this point amendment can't make except the verbal or vocal amendmentsthat are nature of a consequential or formal. A bill must be passed after debate and must be a character of general. It confined to the measures of rejecting or supporting arguments. (Ahmad, 2017).

\subsubsection{Repeated in another House}

When a bill passed in a House then it is sent to the other House (Senate) and then again goes throw by the same process of consideration for agreement. However, the process of law-making is much like the National Assembly.The bills except the finance and money bills are sent for consideration to the Senate after the successful national assembly passage. When a bill passed in a House in which it is originated then it will be transmitted to the other House and in case of acceptance without any amendment it will be send for the president assent.

\subsubsection{Presidential Assent}

The total numbers of parliamentarians of both Houses in their separate sittings, not less than $2 / 3$ majority is required in the case of a bill to amend the constitution. Once a bill passed in a House in which it is originated then it will be transmitted to the other House and in case of acceptance without any amendment it will be send for the presidential assent. Then president have the final authority to pass the bill. He will assent to the bill within 10 days. It is the last stage for becoming a bill to an Act and gained the status of law. In other case if a bill returned by the president assent after reconsideration, then the bill will be reconsidered in the parliament's joint sitting. If the parliament again passed this bill without or with an amendment by majority votes then it will be presented to the president, then in this form it will be presented to the president and he will "give his assent failing which such assent shall be deemed to have been given" (Lauise, 2013). 


\section{Comparative Analysis}

Pakistan's parliamentary system is bicameral and consisted on two Houses, National Assembly and Senate while Canadian parliamentary system of three parts the Crown, House of Commons and Senate. They work together to fulfill the requirements of the people and makes law for the country. Canada has the constitutional monarchy which means all federal laws are made on the Queen's name. This mean Queen is the formal head of state and laws governing Canada recognize by Queen, many vital ceremonial duties are also performed by the queen. Mean wise, parliament is the exclusive representative's institution in Pakistan, which is sole lawmaking authority, where President performs ceremonial duties as the formal head of state. While, leader of the house elected as prime minister and as a prime minister of the state he or she remains the member of the parliamentary legislature.

Canadian House of Commons is a very powerful lower chamber in the process of legislation. The Constitution of Canada endows equal legislative powers to both upper and lower Houses. On the other hand, Pakistan's National Assembly is also a vibrant and visible institution of legislation. Meanwhile the Constitution of 1973 also endows equal legislative powers to both upper and lower Houses of Pakistan. The Parliamentary system of Canada and Pakistan are totally democratic as well as multi-party system and are following the parliamentary form of government which built on the opinion of people. Legislation, representation and the oversight are the key functions ofboth these parliaments. Parliament contributes the elements of the effective governance by playing these roles effectively in both these states.Under the scheme of constitution, parliament does not itself govern on country, but it exercises the meaningful and effective supervision over legislative, executive, and administrative actions through the system of committees and the parliamentary procedures. Parliamentary functions are bound within the federal framework and in the form of written constitution. Its power, jurisdiction, authority and range and scope are also enormous. As compare to the Pakistan's National Assembly the Canadian House of Commons has a rich and long history with years of experimentation and experiences. It has perfected in its functioning and procedures and it has increased its role and powers. Pakistan's National assembly is also considered the most active component for making legislation and keeps check on the government and enjoys an exclusive jurisdiction.

\section{Conclusion}

Parliament is the constitutional expression of the certain ideas.It is an institution of the elected representatives which makes law for the whole nation, state or a country. Parliament of any state ensures the functions of the government and set out these functions in the constitution of the state, resolved and managed the internal threats and crisis and also stopped the violation of the basis and fundamental rights of the citizens of that country. The both houses of these parliaments preserving separate services, which needlessly enhance it to outlay with constructing the better investigation. This study analyzed the legislative process in Canada and Pakistan and presents the comparative study of parliamentary system of both these two countries. Legislative process of both parliaments of Canada and Pakistan are discussed especially. Parliamentary function of legislation and its comparison with other political system became very useful to summarize this research. However, the job done by these Houses is also useful and guideline for the future parliaments to make them more efficient.

\section{References}

Ahmad, T. (February 2017). National Parliaments: Pakistan. Islamabad: The Law Library of Congress, Global Legal Research Center. Retrieved from http://www.law.gov

Barnes, A. (2012). The legislative process : from government policy to proclamation (Revised ed.). (F. English, Trans.) Ottawa: Library of Parliament, Parliamentary Information and Research Service.

Beauchesne, A. (12 March 2012). "Rules and Forms of the House of Commons of Canada: With Annotations and an Extensive Index”. Canada: Nabu Press.

Bildook, K. (2012). Consistency Influence in Parliament: Countering the Centre. Canada: UBC Press.

Bosc, A. G. (14 Dec, 2017). House of Commons Procedure and Practice (3rd ed., Vol. 1). Canada: Editions Yvon Blais.

Bourinot, J. G. (2008). Parliamentary Procedure and Practice in the Dominion of Canada (reprint ed.). (T. B. Flint, Ed.) The Lawbook Exchange, Ltd. 
Franks, C. (1987). The Parliament of Canada. Toronto: University of Toronto Press.

Hasson, F. D. (2017). Post- Legislative Secrutiny Comparative Study of Practices of Post-Legislative Securtiny in Selected Parliaments and the Rational For its Palace in democracy Assistance. London: Westminster Foundation for Democracy.

Hussain, M. (2011). Institution of Parliament in Pakistan: Evolution and Building Process (1947-1970). Journal of Political Studies, 18(2), 77-99.

Jackson, R. J. (2016). Canadian Government in Transition (6th ed.). Canada: Pearson Prentice Hall.

Lauise, A. (2013). Parliament's Role in Pakistan's Democratic Transition. Asia Report, 249. New York: International Crisis Group Working to Prevent Conflict Worldwide.

Macfarlane, E. (2016). Constitutional Amendment in Canada. Canada: University of Tornoto.

Malcolmson, P. (2012). The Canadian Regime. (R. Myers, Ed.) Toronto, Canada: University of Toronto Press.

Marc Basc, A. G. (2017). House of Commons Procedure and Practice (3rd ed., Vol. vol.1). Canada: Éditions Yvon Blais.

Milliken, P. (2005). Guide to the House of Commons (3rd ed.). Ontario: Library and Archives Canada Cataloguing in Publication. Retrieved from ISBN 0-662-68678-0

Pakistan Institute of Legislative Development and Transparency. (2013). 5 year of 13th National Assembly of Pakistan 2008-2013. Islamabad, Pakistan: Pakistan Institute of Legislative Development and Transparency.

Parliamentary Institute of Pakistan Studies. (2014). National Assembly of Pakistan. Islamabad: National Assembly Secretariat.

Peter Milliken. (2009). Our Countary, Our Parliament: A Guide for Learners of English As a Second Language and An Introduction to How Parliament Works. Ontario: Library and Archives Canada Cataloguing in Publication. Retrieved from ISBN 978-0-662-46116-6

Peter Oliver, P. M. (2017). The Oxford Handbook of the Canadian Constitution. New York: Oxford University Press.

Pollard, A. (1926). The Evolution of Parliament (2nd ed.). London: Longmans Green and Co. Retrieved from https://www.amazon.com/Evolution-Parliament-F-Pollard/dp/B002FAXD6G

Rizvi, D. H. (2013). A Narrative of Pakistan's 10 General Elections:1970-2013. Islamabad: Pakistan Institute of Legislative Development and Transparency. doi:ISBN:978-969-558-342-9

Robert Marleau, C. (2009). House of Commons Procedure and Practice. Canada: Parliament House of Commons.

Whitehead, L. (2013, February 16). The Westminster System "Model” or "Muddle"? Taiwan Journal of Democracy, 9-38. 